\title{
Modeling habitat use for dusky dolphin and Commerson's dolphin in Patagonia
}

\author{
Griselda V. Garaffo ${ }^{1, *}$, Silvana L. Dans ${ }^{2,3}$, Susana N. Pedraza ${ }^{2,3}$, Mariana Degrati ${ }^{2,3}$, \\ Adrián Schiavini ${ }^{4,5}$, Raúl González ${ }^{6}$, Enrique A. Crespo ${ }^{2,3}$ \\ ${ }^{1}$ Universidad Nacional de Mar del Plata, Funes 3600, CP (7600) Mar del Plata, Argentina \\ ${ }^{2}$ Centro Nacional Patagónico (CONICET), Boulevard Almirante Brown 2825, CP (9120) Puerto Madryn, Chubut, Argentina \\ ${ }^{3}$ Universidad Nacional de la Patagonia, Boulevard Almirante Brown 3600, CP (9120) Puerto Madryn, Chubut, Argentina \\ ${ }^{4}$ Centro Austral de Investigaciones científicas (CONICET), Houssay 200, CP (V9410) Ushuaia, Tierra del Fuego, \\ Antártica e Islas del Atlántico Sur, Argentina \\ ${ }^{5}$ Wildlife Conservation Society Representación, Amenabar 1595, Buenos Aires, Argentina \\ ${ }^{6}$ Instituto de Biología Marina y Pesquera Almirante Storni, Güemes 1030, CP (8520) San Antonio Oeste, Río Negro, \\ Argentina
}

\begin{abstract}
Several species of small cetaceans inhabit the coastal area of Patagonia (Argentina), but little is known about their distribution and the degree of overlap between them. The goal of the present study was to build habitat-selection models for small cetaceans in order to assess areas of particular importance for the different species. These models were constructed using physiographic and remotely sensed variables. From 1994 to 2007, 13 aerial surveys were conducted along the Patagonian coast (from Golfo San Matías: $40^{\circ} 40^{\prime}-42^{\circ} 14^{\prime} \mathrm{S}, 65^{\circ} 00^{\prime}-63^{\circ} 47^{\prime} \mathrm{W}$ to Bahía de los Nodales: $48^{\circ} 00^{\prime} \mathrm{S}, 65^{\circ} 35^{\prime} \mathrm{W}$ ). A grid of $0.5^{\circ} \times 0.5^{\circ}$ cells was constructed for the study area. Each cell was characterized by environmental variables and by the encounter rate (ER) for each cetacean species. The ER of each species was investigated in relation to environmental variables using generalized linear models, and model averaging (multimodel inference) was used to obtain a predicted ER for the different species. The correlation between the ER of different species was analyzed by Spearman rank correlation. The environmental variables that were found to be significant predictors of species distribution differed between species. The ERs of dusky dolphin Lagenorhynchus obscurus and Peale's dolphin L. australis showed a positive relationship. Commerson's dolphin Cephalorhynchus commersonii presented a more coastal distribution than the other species, and individuals were more often found feeding in estuarine zones. Knowledge of the patterns of distribution of small cetaceans along the Patagonian coast provides baseline knowledge of how these species interact with each other and their environment. Such information should be considered when managing potential areas of conflict between coastal small cetaceans and human activities.
\end{abstract}

KEY WORDS: Distribution modeling · Dolphins - Generalized linear model · Habitat selection · Patagonia Resale or republication not permitted without written consent of the publisher

\section{INTRODUCTION}

The coastal area of Patagonia, Argentina, is a highly productive environment, and is therefore very important for both regional and local economies and marine life. Many species of seabirds, marine mammals, migratory birds, fishes, mollusks, and crustaceans breed and forage along these coasts. Several species of small cetaceans inhabit these waters. Among the most abundant are the dusky dolphin Lagenorhynchus obscurus, Peale's dolphin L. australis, Commerson's dolphin Cephalorhynchus commersonii, the common 
dolphin Delphinus delphis, the bottlenose dolphin Tursiops truncatus, Burmeister's porpoise Phocoena spinipinnis, and the spectacled porpoise $P$. dioptrica. Little is known about the distribution of these species within the Patagonian shelf and the degree of overlap between them. A considerable degree of sympatry between the dusky dolphin and Peale's dolphin exists, although these species may use different habitats (Crespo et al. 1997a, Brownell et al. 1998).

Co-occurrence of 2 or more species in the same geographic area, i.e. sympatry, is common in marine environments, where important resources such as prey are grouped and patchily distributed. When different species require similar resources and these resources are limited, temporal or spatial segregation may occur to reduce competition (Roughgarden 1976). Such habitat partitioning has been observed in many marine species (Gowans \& Whitehead 1995). Alternatively, species may be able to coexist as a result of dietary differences or by using the area for different functions, so that they do not exert a strong competitive pressure on each other (Bearzi 2005).

While knowledge of a species' distribution is a fundamental part of ecological studies, being able to predict the distribution is essential for conservation and population management (Boyce \& McDonald 1999, Hill 1999, Cabeza et al. 2004, Gibson et al. 2004, Jeganathan et al. 2004). Predictive habitat models can provide a powerful tool for assessing areas of high relative density, and for determining the factors that influence distribution (Redfern et al. 2006). In turn, the identification of these key areas for each species provides a focus for conservation action and appropriate management. Marine mammals are potential indicator species, in that their protection should also ensure the health of other key components of a marine ecosystem (Hooker \& Gerber 2004).

Small cetaceans are subject to a wide variety of anthropogenic effects, including direct mortality (e.g. bycatch or whaling), competition for prey, contamination from chemical compounds, degradation and loss of important habitat, and effects from global climate change (Whitehead et al. 2000, Bjørge 2001, Evans 2002). Many authors have used cetacean habitat models to establish marine protected areas (Hooker et al. 1999, Cañadas et al. 2002, Bailey \& Thompson 2009), predict which areas present a greater probability of occurrence of species (Garaffo et al. 2010), improve abundance estimates (Reilly \& Fiedler 1994, Forney 2000), understand cetacean-fisheries interactions (Torres et al. 2003, Kaschner 2004), or to study habitat segregation of ecologically similar species or different ecotypes (Reilly 1990, Waring et al. 2001). Several studies have described cetaceans' distribution and habitat preferences by linking their presence to different habitat variables (Forcada 2002). Such variables include sea temperature (Brown \& Winn 1989, Baumgartner et al. 2001, Cañadas et al. 2005, Panigada et al. 2008, Garaffo et al. 2010), bathymetric and physiographic variables (Baumgartner 1997, Carretta et al. 2001, Cañadas et al. 2002, 2005, Torres et al. 2003, Panigada et al. 2005, 2008, Garaffo et al. 2007, 2010, Ingram et al. 2007, Bailey \& Thompson 2009, Embling et al. 2010), currents and frontal systems (Tynan 1998, Mendes et al. 2002, Johnston et al. 2005a,b, Pedraza 2008), primary production (Littaye et al. 2004, Panigada et al. 2008, Garaffo et al. 2010), and prey distribution (Jaquet \& Gendron 2002, Baumgartner et al. 2003, Macleod et al. 2004).

In the Patagonian waters of Argentina, the main threats to small cetaceans are incidental mortality in fishing gear, indirect effects of fisheries, tourism interactions, and more recently, offshore oil exploration (Corcuera et al. 1994, Crespo et al. 1994, 1997b, 2000, Goodall et al. 1995, Dans et al. 1997, 2003, 2008, Coscarella et al. 2003). The dusky dolphin, Peale's dolphin, Commerson's dolphin, the common dolphin, the bottlenose dolphin, and Burmeister's porpoise are species that suffer both direct and indirect effects from interaction with fisheries operating in the Argentine Sea (Corcuera et al. 1994, Crespo et al. 1994, 1997b, 2000, Goodall et al. 1995, Dans et al. 1997, 2003). In addition, the dusky dolphin is a target of commercial whale watching in the Golfo Nuevo, as is Commerson's dolphin near the Chubut River and the estuary of Puerto Deseado (Coscarella et al. 2003, Dans et al. 2008).

Predictive habitat models for different species can provide a background for empirically based recommendations for cetacean conservation. Habitatselection models have been used successfully for the dusky dolphin in Golfo Nuevo ( $2500 \mathrm{~km}^{2}$ in area) (Garaffo et al. 2010), showing that physiography, sea surface temperature (SST), and chlorophyll a (Chl a) concentration were all important in determining which areas would have a higher probability of dusky dolphin occurrence. The goal of the present work was to build habitat-selection models for the 2 most abundant small cetacean species (dusky dolphin and Commerson's dolphin) in the Patagonian marine system (from Golfo San Matías to Bahía de los Nodales), using both physiographic (depth and distance from shore [Dfs]) and remotely sensed environmental variables (SST and $\mathrm{Chl}$ a). This is the first large-scale spatial study to use habitat-selection models for small cetaceans in the southwest Atlantic Ocean, and the results will help differentiate among the species' habitat preferences, which in turn is useful for conservation and management. 


\section{MATERIALS AND METHODS}

Data collection. From 1994 to 2007 (see Table 1), 13 aerial surveys were conducted along Patagonian coastal and neritic waters (from Golfo San Matías: $40^{\circ} 40^{\prime}-42^{\circ} 14^{\prime} \mathrm{S}, 65^{\circ} 00^{\prime}-63^{\circ} 47^{\prime} \mathrm{W}$ to Bahía de los Nodales: $48^{\circ} 00^{\prime} \mathrm{S}, 65^{\circ} 35^{\prime} \mathrm{W}_{i} \sim 53000 \mathrm{~km}^{2}$ in area; Fig. 1). The surveys were carried out using 2 different highwing twin-engine aircrafts, depending on the year of the survey: a CASA C-212 belonging to Prefectura Naval Argentina (National Coast Guard of Argentina) and a Cessna 337 Super-Skymaster. On each flight in the Cessna 337, 3 trained people traveled: 1 recorder and 2 observers ( 1 on each side of the plane); and 5 trained people traveled on each flight in the CASA C-212: 4 observers and 1 recorder. Each survey design was planned in advance to be between the shoreline and a distance of $\sim 100 \mathrm{~km}$ from the coast and at a height of $150 \mathrm{~m}$. The design was based on both the availability, the cost and the range of the aircraft, and on the weather conditions for safety and security. Surveys were undertaken on days with a calm sea state (Beaufort $\leq 3$ ). Data on survey effort and cetacean locations were recorded using a GPS (Fig. 1). The original aim of these surveys was to estimate the abundance of the cetacean species. However, given the quality of information obtained, it was possible to use these surveys to relate the distribution of different species to environmental variables.

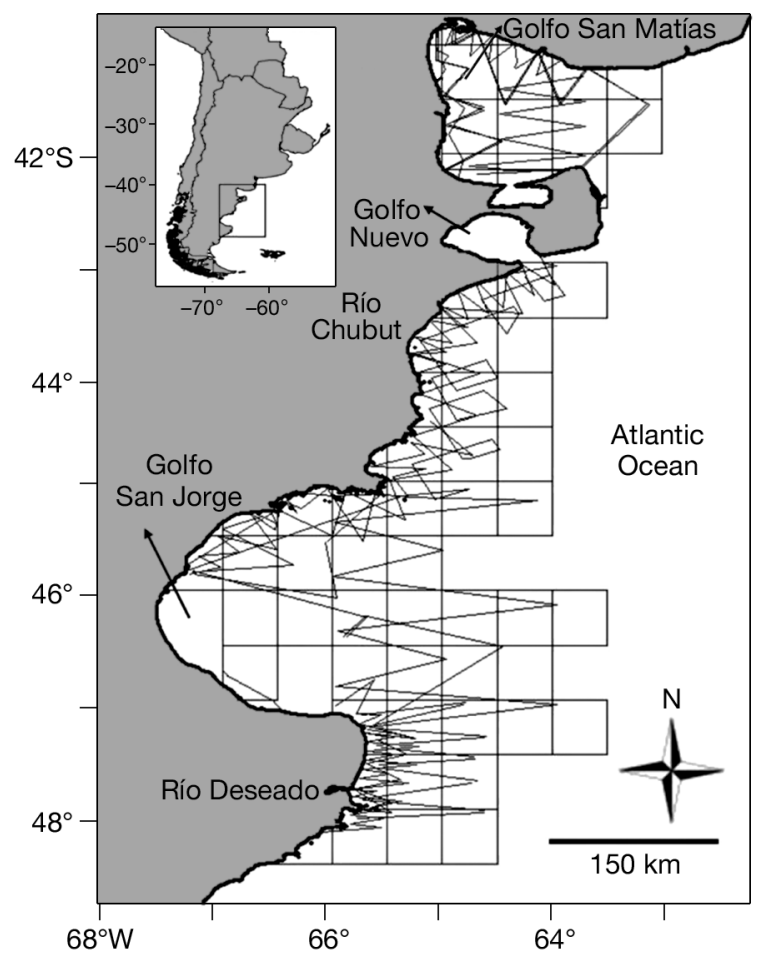

Fig. 1. Study area showing aerial survey transects conducted from 1994 to 2007 (effort) and $0.5^{\circ} \times 0.5^{\circ}$ grid cells
Environmental and biological data. A grid of $0.5^{\circ} \times$ $0.5^{\circ}$ squares $\left(2300 \mathrm{~km}^{2}\right.$ cell $\left.{ }^{-1}\right)$ was constructed on the study area. Each cell of the grid was characterized by depth, Dfs, SST, Chl $a$, and distance to the nearest large river mouth (Drm). Because 2 of the 13 aerial surveys were conducted during the cold season (May and August), cells were also characterized according to seasonal variability in SST ( $\left.\mathrm{SST}_{\text {var }}\right)$ and Chl a (Chl $\left.a_{\text {var }}\right)$. Depth and Dfs data were obtained from a nautical chart (H-50, Naval Hydrographic Service, Buenos Aires). Mean depth was calculated by averaging all values within a cell, and Dfs was calculated as the distance from the central point of the cell to the closest point on the coastline.

Mean annual and seasonal SST data were obtained from Piola (2008a). The original data were extracted from satellite images (National Oceanic and Atmospheric Administration, NOAA) (http://podaac.jpl.nasa. gov). $\mathrm{SST}_{\text {var }}$ in each cell was calculated as: mean summer SST - mean winter SST. The annual SST map and $\mathrm{SST}_{\text {var }}$ were overlaid on the grid. Mean annual and seasonal concentrations of $\mathrm{Chl} \mathrm{a}\left(\mathrm{mg} \mathrm{m}^{-3}\right)$ were obtained from Piola (2008b). SeaWiFS images were extracted from http://oceancolor.gsfc.nasa.gov. Chl $a_{\text {var }}$ in each cell was calculated as: mean summer $\mathrm{Chl} a-$ mean winter $\mathrm{Chl} a$. The annual Chl a concentration map and Chl $a_{\text {var }}$ were overlaid on the grid. Then, each cell of the grid was characterized for annual SST, annual Chl $a, \mathrm{SST}_{\text {var, }}$ and Chl $a_{\text {var }}$. Finally, each grid cell was characterized by the encounter rate (ER) for each small cetacean species. The ER in each cell was calculated as:

$$
\begin{gathered}
\mathrm{ER}=(\text { Number of sighted groups } / \\
\mathrm{km} \text { of survey effort }) \times 100
\end{gathered}
$$

Because the cells intercepted by the coast were smaller than open-water cells, ER was corrected by the proportion of effective area of the cell (surface ratio with respect to a whole cell) as follows:

$$
\mathrm{ER}_{\text {corrected }}=\mathrm{ER} / \text { proportion of effective area of cell }
$$

A group was defined as any group of animals closely engaged in the same activity and moving in the same direction. The survey effort was quantified as the sum of kilometers traveled in each cell during the whole study (from 1994 to 2007).

Data analysis. Generalized linear models (GLMs; Dobson 2002) were used to investigate the distribution of each small cetacean species in relation to environmental variables. The explanatory variables evaluated were depth, Dfs, SST, Chl a, Drm, SST var, Chl $a_{\text {var }}$ depth $^{2}{ }^{2}$ Dfs $^{2}$, $\mathrm{SST}^{2}, \mathrm{Chl} a^{2}, \mathrm{Drm}^{2}, \mathrm{SST}_{\text {var }}{ }^{2}, \mathrm{Chl} a_{\text {var }}{ }^{2}$, and all interactions among them. Candidate variables were chosen based on their hypothesized biological importance and were then treated as continuous covariates. SPSS version 15 statistical software was used for data analyses. 
The response variable was the ER of a given species within each cell. The models for each species were fitted assuming a Poisson error distribution, with a loglink function. In the case of existing overdispersion, the standard errors of the parameter estimates and related statistics were computed taking into account the overdispersion (McCullagh \& Nelder 1989). The best model was selected for each species using the Akaike information criterion (AIC) (Akaike 1973). Models with a difference in AIC $(\triangle \mathrm{AIC})<2$ were considered to have equivalent support from the data (Burnham \& Anderson 2002). $\triangle \mathrm{AIC}$ and Akaike weights $\left(w_{\mathrm{i}}\right)$ were calculated for each model. When $>1$ model had substantial support, model averaging (a form of multimodel inference) was used (Burnham \& Anderson 2002). Part of multimodel inference includes ranking the fitted models from the best to the worst based on the AIC, and then scaling to obtain the relative plausibility of each fitted model by a weight of evidence (in this case $w_{\mathrm{i}}$ ) relative to the selected best model (lowest AIC). Then, a weighted estimate of the predicted value, weighting the predictions by $w_{\mathrm{i}}$, was computed. Therefore, this method allows formal statistical inference from all models in the set. The model fit and the selection of predictive variables deemed to be important often reflect the selection process more than biological relevance (MacNally 2000). In the present study, the fit and complexity of the models were evaluated in successive steps to avoid overfitting, until a model with sufficient predictive power was obtained.

Spearman rank correlation (Siegel \& Castellan 1995) was used to investigate the correlation between the ER of different species. In this way, an indicator of species overlap was retrieved.

\section{RESULTS}

A total of $10600 \mathrm{~km}$ was surveyed (Fig. 1) during 13 aerial surveys. Six dolphin species were recorded, including 101 groups of dusky dolphin and 65 groups of Commerson's dolphin (Table 1). Thirty groups of common dolphin were sighted; however, the present study only covered a small portion (the most southern part) of this species' distribution. Therefore, no analysis of its relationship with environmental variables was made due to the bias in the surveys; this species is very common along the coast of Buenos Aires province and north of Patagonia, with the southernmost sightings recorded in Golfo Nuevo. In addition, $<15$ groups in total were recorded for bottlenose dolphin, Burmeister's porpoise, and Peale's dolphin; no analyses of their relationships with environmental variables were made due to the small sample size.
The environmental variables that were found to be significant predictors of distribution differed between dusky and Commerson's dolphins. Table 2 shows the models with $\triangle \mathrm{AIC}<2$ for the dusky dolphin. The model with the lowest AIC value shows that ER was significantly related to $\mathrm{SST}_{\text {var, }} \mathrm{Dfs}, \mathrm{Dfs}^{2}, \mathrm{SST}^{2}$, and $\mathrm{Chl} a^{2}$, and to the interaction between Dfs and $\mathrm{Chl} a$, and between SST and Chl a. However, this model was not clearly the best as $W_{\mathrm{i}}=0.093$, which is a very low value. A model can be considered the best when $w_{\mathrm{i}}$ is $\sim 1$. and so the average model was calculated. Following model averaging, the highest predicted values of ER occurred in cells with high temporal variability in SST (Fig. 2a), between 30 and $60 \mathrm{~km}$ from shore (Fig. 2b, SST between 12 and $13^{\circ} \mathrm{C}$ (Fig. 2c), and cells with intermediate values of Chl a (Fig. 2d). The highest ER of dusky dolphin was therefore predicted to occur in the central zone of the study area (Fig. 3).

Table 3 shows the models with $\triangle \mathrm{AIC}<2$ for Commerson's dolphin. The model with the lowest AIC value shows that ER was significantly related to Drm, Drm², $\mathrm{SST}_{\text {, }} \mathrm{SST}^{2}$, and Chl $a^{2}$. However, this model was not clearly the best ( $w_{\mathrm{i}}=0.089$, see previous paragraph) and so the model averaging was done. Model averaging showed that the highest predicted values of ER occurred in areas close to the river mouth (Fig. 4a) and in cells with high values of Chl a (Fig. 4b). The relationship with SST was bimodal, peaking in colder areas of 9 to $10^{\circ} \mathrm{C}$ and in warmer areas of 12 to $13^{\circ} \mathrm{C}$ (Fig. 4c). The highest ER was predicted to occur in the surrounding area of both Chubut and Deseado river mouths (Fig. 5).

Among all species, only the correlation between ER of the dusky dolphin and ER of Peale's dolphin was significant (Spearman rank correlation: $r_{s}=0.357$, $\mathrm{n}=60, \mathrm{p}=0.0051$ ).

Table 1. Lagenorhynchus obscurus and Cephalorhynchus commersonii. Survey effort and number of groups of each species recorded for each aerial survey, from 1994 to 2007

\begin{tabular}{|lccc|}
\hline Date & $\begin{array}{c}\text { Survey } \\
\text { effort } \\
(\mathrm{km})\end{array}$ & $\begin{array}{c}\text { Dusky } \\
\text { dolphin }\end{array}$ & $\begin{array}{c}\text { Nommerson's } \\
\text { dolphin }\end{array}$ \\
\hline 17 Nov 94 & 800 & 0 & 21 \\
25 Nov 94 & 700 & 0 & 1 \\
9 May 95 & 770 & 4 & 0 \\
31 Aug 95 & 770 & 2 & 0 \\
8 Nov 95 & 1040 & 46 & 3 \\
27 Nov 95 & 1200 & 16 & 3 \\
12 Dec 95 & 730 & 0 & 12 \\
4 Dec 96 & 780 & 6 & 0 \\
14 Feb 00 & 510 & 16 & 9 \\
7 Feb 03 & 850 & 3 & 0 \\
9 Feb 03 & 950 & 1 & 0 \\
4 Oct 07 & 570 & 0 & 4 \\
29 Nov 07 & 930 & 7 & 65 \\
Total & & 101 & \\
\hline
\end{tabular}


Table 2. Lagenorhynchus obscurus. Models with $\Delta \mathrm{AIC}<2$. All were generalized linear models with a Poisson error structure and log-link function, relating environmental variables to the encounter rate for dusky dolphin. AIC = Akaike information criterion, $w_{\mathrm{i}}=$ Akaike weight, $\mathrm{Chl} a=$ chlorophyll $a$ concentration, $\mathrm{Chl} a_{\mathrm{var}}=$ temporal variability in Chl $a$, Dfs = distance from shore, $\mathrm{SST}$ = sea surface temperature, $\mathrm{SST}_{\mathrm{var}}=$ temporal variability in SST. The symbol ' $:$ ' means an interaction between variables

\begin{tabular}{|c|c|c|c|}
\hline Model & AIC & $\Delta \mathrm{AIC}$ & $w_{\mathrm{i}}$ \\
\hline $\mathrm{SST}_{\mathrm{var}}$ Dfs Dfs ${ }^{2} \mathrm{SST}^{2} \mathrm{Chl} a^{2}$ Dfs:Chl a SST:Chl $a$ & 184.127 & 0.000 & 0.093 \\
\hline $\mathrm{SST}_{\text {var }}$ Dfs SST Dfs ${ }^{2} \mathrm{SST}^{2}$ Chl $a^{2}$ Dfs:Chl a SST:Chl a & 184.238 & 0.111 & 0.088 \\
\hline Dfs Dfs ${ }^{2} \mathrm{SST}_{\mathrm{var}}{ }^{2} \mathrm{SST}^{2} \mathrm{Chl} a^{2} \mathrm{Dfs}: \mathrm{Chl}$ a SST:Chl a & 184.323 & 0.195 & 0.085 \\
\hline Dfs SST SST ${ }_{\text {var }}^{2} \operatorname{Dfs}^{2} \mathrm{SST}^{2}$ Chl $a^{2}$ Dfs:Chl a SST:Chl $a$ & 184.393 & 0.266 & 0.082 \\
\hline $\mathrm{SST}_{\mathrm{var}}$ Dfs SST Chl $a_{\mathrm{var}}{ }^{2} \mathrm{Dfs}^{2} \mathrm{SST}^{2} \mathrm{Chl} a^{2}$ Dfs:Chl a SST:Chl $a$ & 185.165 & 1.038 & 0.055 \\
\hline $\mathrm{SST}_{\text {var }}$ Dfs Chl $a \mathrm{Dfs}^{2} \mathrm{SST}^{2} \mathrm{Chl} a^{2}$ Dfs:Chl $a$ SST:Chl $a$ & 185.279 & 1.152 & 0.052 \\
\hline Dfs SST SST ${ }_{\text {var }}^{2}$ Chl $a_{\text {var }}^{2}$ Dfs $^{2}$ SST $^{2}$ Chl $a^{2}$ Dfs:Chl a SST:Chl a & 185.339 & 1.212 & 0.051 \\
\hline $\mathrm{SST}_{\mathrm{var}}$ Dfs SST Chl $a \mathrm{Dfs}^{2} \mathrm{SST}^{2} \mathrm{Chl} a^{2} \mathrm{Dfs}: \mathrm{Chl} a$ & 185.340 & 1.213 & 0.051 \\
\hline Dfs SST Chl $a \mathrm{SST}_{\mathrm{var}}{ }^{2} \mathrm{Dfs}^{2} \mathrm{SST}^{2} \mathrm{Chl} a^{2} \mathrm{Dfs}: \mathrm{Chl} a$ & 185.468 & 1.341 & 0.048 \\
\hline $\mathrm{SST}_{\mathrm{var}}$ Dfs Chl a Dfs ${ }^{2} \mathrm{SST}^{2}$ Dfs:Chl a SST:Chl a & 185.483 & 1.356 & 0.047 \\
\hline Dfs Chl $a \mathrm{SST}_{\mathrm{var}}^{2} \mathrm{Dfs}^{2} \mathrm{SST}^{2} \mathrm{Chl} a^{2} \mathrm{Dfs}: \mathrm{Chl}$ a SST:Chl a & 185.531 & 1.404 & 0.046 \\
\hline $\mathrm{SST}_{\mathrm{var}}$ Dfs SST Chl a Chl $a_{\mathrm{var}}{ }^{2} \mathrm{Dfs}^{2} \mathrm{SST}^{2} \mathrm{Chl} a^{2} \mathrm{Dfs}: \mathrm{Chl} a$ & 185.785 & 1.658 & 0.041 \\
\hline 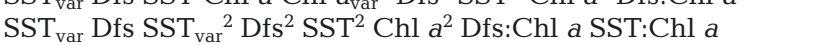 & 185.848 & 1.720 & 0.039 \\
\hline Dfs Chl a $\mathrm{SST}_{\mathrm{var}}{ }^{2} \mathrm{Dfs}^{2} \mathrm{SST}^{2}$ Dfs:Chl a SST:Chl a & 185.858 & 1.731 & 0.039 \\
\hline $\mathrm{SST}_{\text {var }}$ Dfs SST SST var $^{2} \mathrm{Dfs}^{2} \mathrm{SST}^{2} \mathrm{Chl} a^{2}$ Dfs:Chl $a$ SST:Chl $a$ & 185.892 & 1.765 & 0.039 \\
\hline Dfs SST Chl a Chl $a_{\text {var }}^{2} \mathrm{SST}_{\mathrm{var}}^{2} \mathrm{Dfs}^{2} \mathrm{SST}^{2} \mathrm{Chl} a^{2} \mathrm{Dfs}: \mathrm{Chl} a$ & 185.932 & 1.805 & 0.038 \\
\hline Chl $a_{\text {var }}$ SST $_{\text {var }}$ Dfs SST Dfs ${ }^{2}$ SST $^{2}$ Chl $a^{2}$ Dfs:Chl a SST:Chl $a$ & 186.036 & 1.908 & 0.036 \\
\hline $\mathrm{SST}_{\mathrm{var}}$ Dfs Chl $a_{\mathrm{var}}{ }^{2} \mathrm{Dfs}^{2} \mathrm{SST}^{2} \mathrm{Chl} a^{2} \mathrm{Dfs}: \mathrm{Chl}$ a SST:Chl $a$ & 186.048 & 1.921 & 0.035 \\
\hline Chl $a_{\mathrm{var}} \mathrm{SST}_{\mathrm{var}}$ Dfs Dfs ${ }^{2} \mathrm{SST}^{2}$ Chl $a^{2}$ Dfs:Chl a SST:Chl $a$ & 186.117 & 1.990 & 0.034 \\
\hline
\end{tabular}
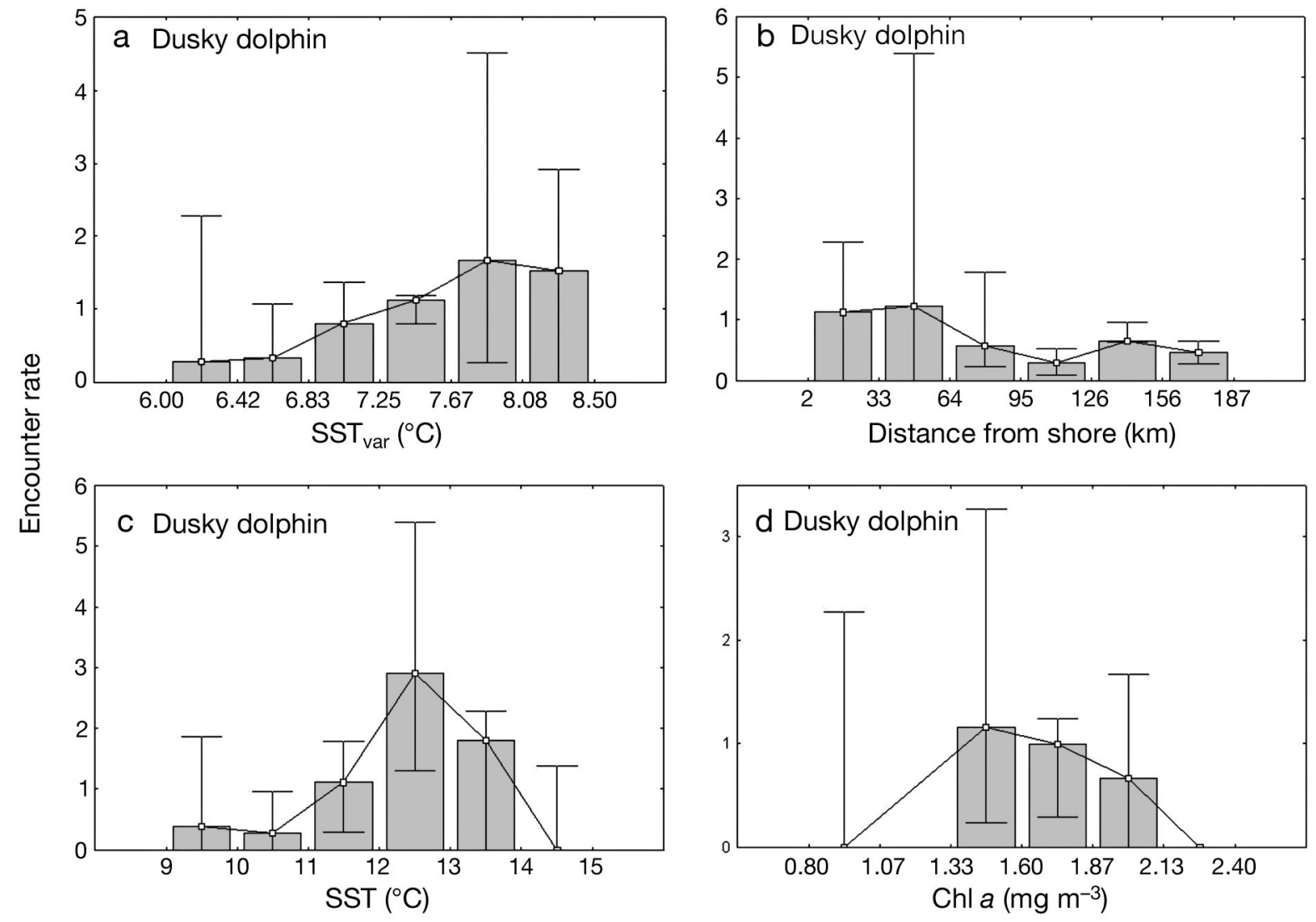

Fig. 2. Lagenorhynchus obscurus. Mean predicted encounter rate for dusky dolphin by average model for differences in (a) temporal variability in sea surface temperature $\left(\mathrm{SST}_{\mathrm{var}}\right)$, (b) distance from shore, (c) sea surface temperature (SST), and (d) chlorophyll a concentration (Chl a). Error bars indicate non-outlier ranges 


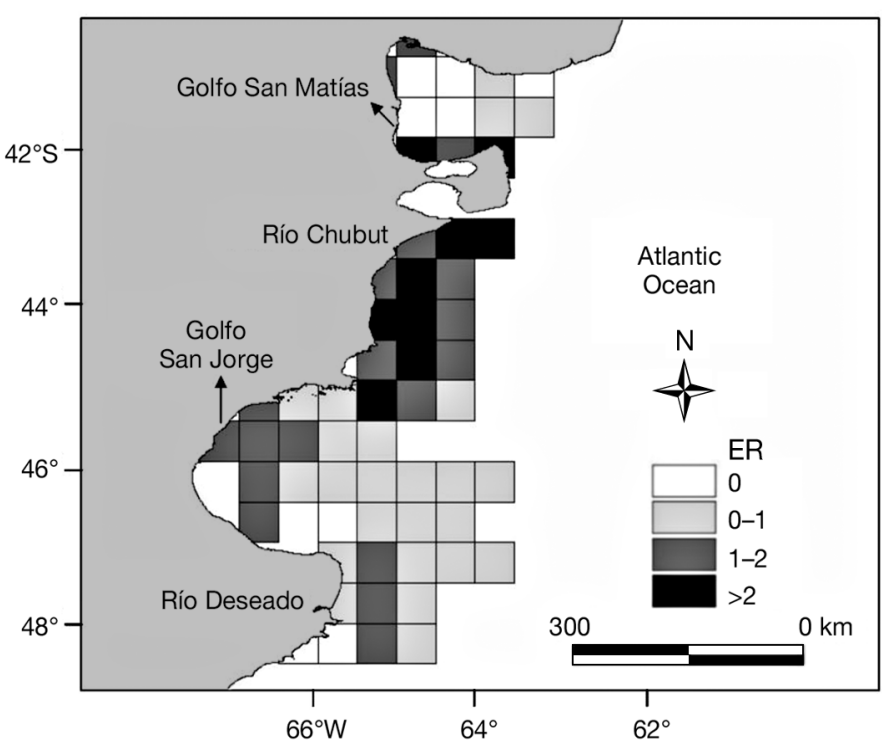

Fig. 3. Lagenorhynchus obscurus. Predicted encounter rates $\left(\mathrm{ER}_{i}\right.$ according to average model) within $0.5^{\circ} \times 0.5^{\circ}$ grid cells

Table 3. Cephalorhynchus commersonii. Models with $\Delta \mathrm{AIC}<2$. All were generalized linear models with a Poisson error structure and log-link function, relating environmental variables to the encounter rate for Commerson's dolphin. AIC = Akaike information criterion, $w_{\mathrm{i}}=$ Akaike weight, $\mathrm{Chl} a=$ chlorophyll $\mathrm{a}$ concentration, Chl $a_{\text {var }}=$ temporal variability in Chl $a$, Dfs $=$ distance from shore, Drm $=$ distance to the river mouth, $\mathrm{SST}=$ sea surface temperature, $\mathrm{SST}_{\mathrm{var}}=$ temporal variability in SST. The symbol ' $:$ ' means an interaction between variables

\begin{tabular}{|c|c|c|c|}
\hline Model & AIC & $\Delta \mathrm{AIC}$ & $w_{\mathrm{i}}$ \\
\hline Drm SST Drm ${ }^{2} \mathrm{SST}^{2} \mathrm{Chl} a^{2}$ & 148.287 & 0.000 & 0.089 \\
\hline Drm Depth SST Drm ${ }^{2}$ Depth $^{2} \mathrm{SST}^{2}$ & 148.764 & 0.477 & 0.070 \\
\hline Drm SST Drm ${ }^{2} \mathrm{SST}^{2} \mathrm{Chl} a^{2}$ & 148.881 & 0.594 & 0.066 \\
\hline Drm SST Chl a $\mathrm{Drm}^{2} \mathrm{SST}^{2} \mathrm{Chl} a^{2}$ & 149.070 & 0.784 & 0.060 \\
\hline Drm SST Drm ${ }^{2} \mathrm{SST}^{2} \mathrm{SST}$ :Chl a & 149.219 & 0.932 & 0.056 \\
\hline Drm Depth Depth ${ }^{2}$ & 149.301 & 1.015 & 0.054 \\
\hline Depth SST Depth ${ }^{2} \mathrm{SST}^{2}$ & 149.317 & 1.031 & 0.053 \\
\hline Drm SST Drm ${ }^{2} \mathrm{SST}^{2} \mathrm{Chl} a^{2} \mathrm{SST}: \mathrm{Chl} a$ & 149.476 & 1.189 & 0.049 \\
\hline Drm SST Drm ${ }^{2} \mathrm{SST}^{2}$ & 149.493 & 1.206 & 0.049 \\
\hline Drm SST Drm ${ }^{2} \mathrm{SST}^{2} \mathrm{Chl} a^{2}$ Dfs:Chl $a$ & 149.623 & 1.335 & 0.046 \\
\hline Drm Depth SST Drm ${ }^{2} \mathrm{SST}^{2}$ & 149.696 & 1.410 & 0.044 \\
\hline Depth Depth ${ }^{2} \mathrm{SST}^{2}$ & 149.817 & 1.530 & 0.042 \\
\hline Depth Drm ${ }^{2}$ Depth $^{2}$ & 149.862 & 1.575 & 0.041 \\
\hline $\mathrm{SST}_{\mathrm{var}}$ Drm SST Drm ${ }^{2} \mathrm{SST}^{2} \mathrm{Chl} a^{2}$ & 149.934 & 1.647 & 0.039 \\
\hline Drm SST Chl a Drm ${ }^{2} \mathrm{SST}^{2} \mathrm{Chl} a^{2} \mathrm{Dfs}: \mathrm{Chl} a$ & 150.104 & 1.8175 & 0.036 \\
\hline Drm SST Drm ${ }^{2} \mathrm{SST}^{2}$ Dfs:Chl a & 150.133 & 1.847 & 0.035 \\
\hline $\mathrm{SST}_{\mathrm{var}}$ Drm Depth SST Drm ${ }^{2}$ Depth $^{2} \mathrm{SST}^{2}$ & 150.160 & 1.874 & 0.035 \\
\hline Drm Drm ${ }^{2} \mathrm{Chl} a^{2}$ & 150.204 & 1.917 & 0.034 \\
\hline Drm SST Drm ${ }^{2} \mathrm{SST}^{2} \mathrm{Chl} a^{2}$ & 150.245 & 1.958 & 0.034 \\
\hline Drm Depth SST Drm ${ }^{2} \mathrm{SST}^{2} \mathrm{Chl} a^{2}$ & 150.262 & 1.975 & 0.033 \\
\hline Chl $a_{\text {var }}$ Drm SST Drm ${ }^{2}$ SST $^{2}$ SST:Chl a & 150.275 & 1.988 & 0.033 \\
\hline
\end{tabular}

\section{DISCUSSION}

The present study offers the first assessment of the distribution and occurrence of small cetaceans in the marine system of Patagonia in relation to environmental variables. ERs for cetaceans were modeled using GLMs in order to select covariates driving the cetacean presence in the area and then model averaging (a form of multimodel inference) was performed. This approach has practical advantages. Where a modelaveraged estimator can be used, it appears to have better precision and reduced bias compared to the estimator from the selected 'best' model (Burnham \& Anderson 2002).

Sightings of different species were not distributed evenly within the study area. The environmental variables that significantly predicted cetaceans' distribution differed between species, which allows us to make inferences about species' habitat preferences. When a resource is used in a way that is disproportionate to how it is available in the environment, this can be used to infer species' preferences. So, when analyzing several species simultaneously in the same area, a differential use of the environment by each species may be seen. Modeling of habitat selection allowed for a more holistic approach and the correlation test revealed overlaps between the different species.

In general, studies of correlation between environmental variables and sightings of dolphins use data from the same month of a survey. In the present study, SST and Chl a concentration maps (annual and seasonal) extracted from Piola $(2008 \mathrm{a}, \mathrm{b})$ were used to characterize the area. This data treatment is considered valid because records of SST and Chl a for the Southwest Atlantic Ocean, and especially for our study area, have shown a stable interannual pattern (Acha et al. 2004, Piola 2008c, Rivas 2010). Even though the data employed in th present study for SST (1985 to 1997) were gathered $>10$ yr ago, only minimal if any changes in oceanographic patterns caused by global warming have been reported since then (Piola 2008c). Indeed, recent studies (Belkin 2009, Rivas 2010) have shown that the increment in SST in the Patagonian shelf ecosystem during the 1982-2006 period was negligible, ranging between 0.06 and $0.08^{\circ} \mathrm{C}$ decade $^{-1}$. 

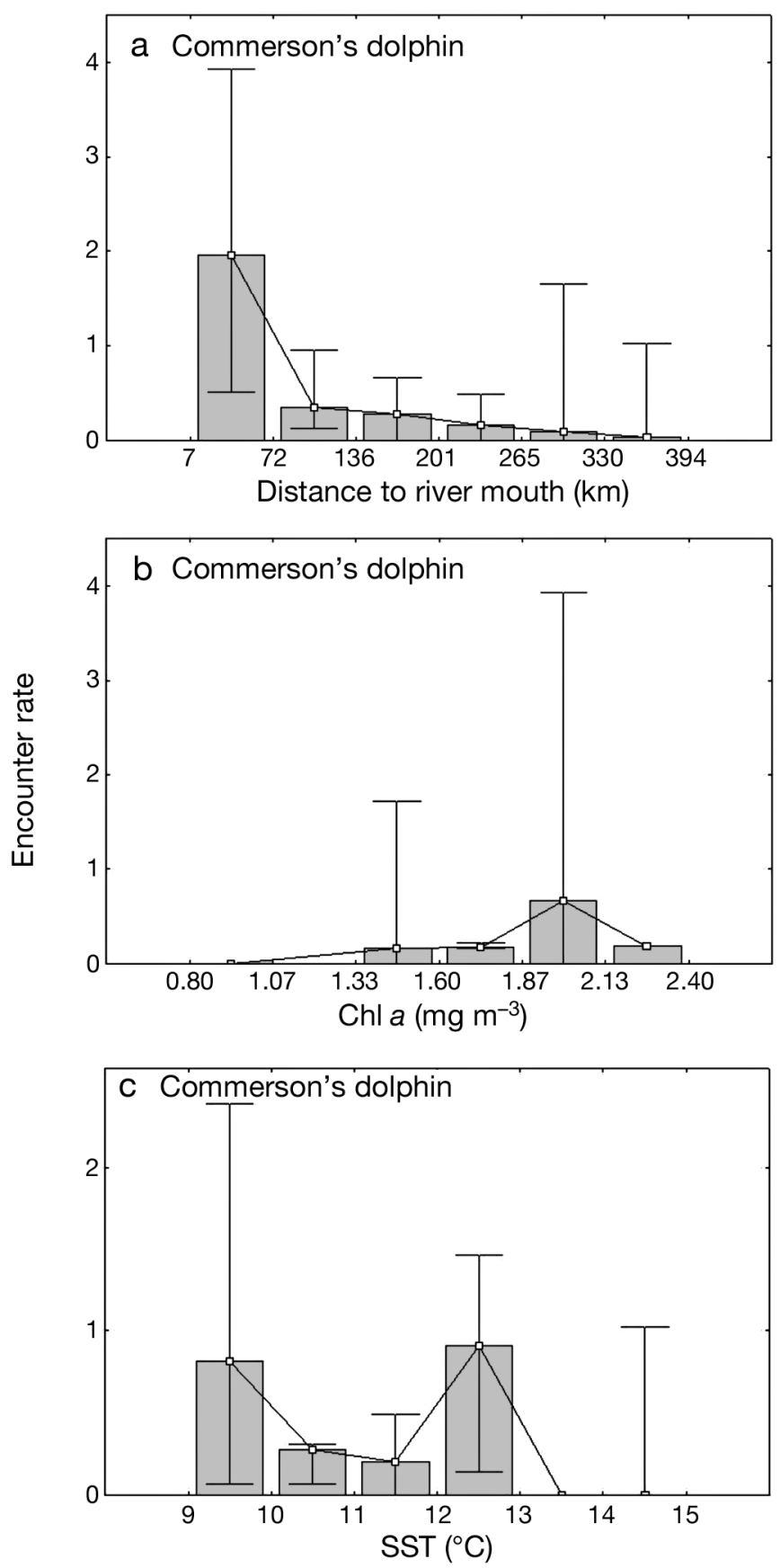

Fig. 4. Cephalorhynchus commersonii. Mean predicted encounter rate for Commerson's dolphin by average model for differences in (a) distance to river mouth, (b) chlorophyll a concentration ( $\mathrm{Chl} \mathrm{a}$ ), and (c) sea surface temperature (SST). Error bars indicate non-outlier ranges

The distribution of dusky dolphin and Peale's dolphin would be expected to be similar, since the ERs of these species showed a positive relationship. Even though Brownell (1974) and Mitchell (1975) proposed that dusky and Peale's dolphins showed an allopatric distribution in the Atlantic Ocean, both species have

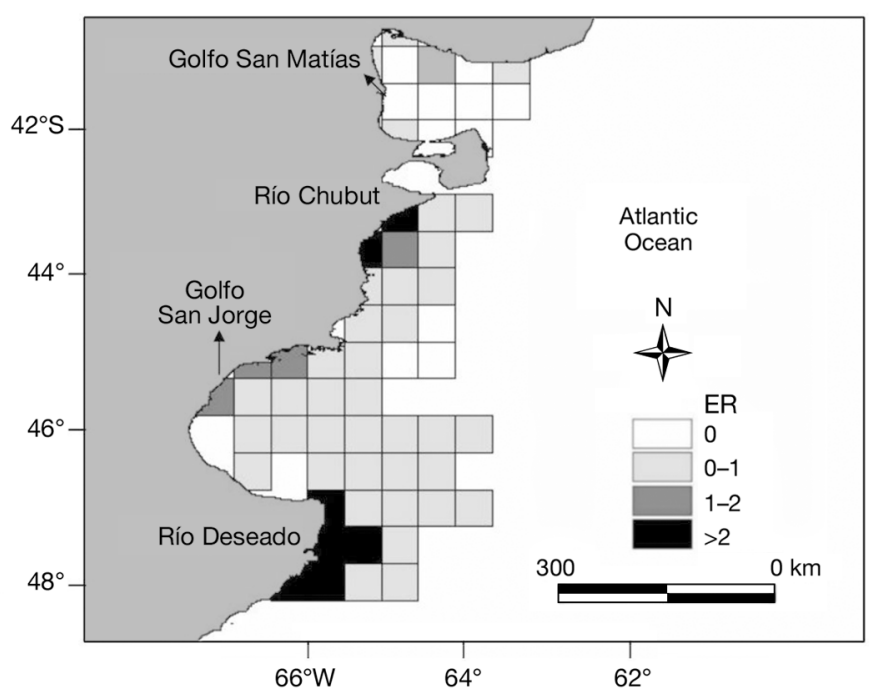

Fig. 5. Cephalorhynchus commersonii. Predicted encounter rates $\left(\mathrm{ER}_{;}\right.$according to average model) within $0.5^{\circ} \times 0.5^{\circ}$ grid cells

been frequently sighted in a large area between $42^{\circ}$ and $55^{\circ} \mathrm{S}$, overlapping in at least part of their distribution (Van Waerebeek 1992, Goodall et al. 1997). The results of the present study support the hypothesis of an overlapping distribution for these 2 species. However, they exploit different subdivisions of habitat and have clearly different social and feeding strategies (Brownell et al. 1998). This would indicate that these 2 species share space but use different food resources. On the Patagonian coast, Peale's dolphin is associated with coastal kelp Macrocystis pyrifera beds (de Haro \& Iñiguez 1997, Lescrauwaet 1997). The fishes associated with this kelp have been found in Peale's dolphin's diet. Its main prey are the pink cusk-eel Genypterus blacodes, shrimp (Pleoticus muelleri), squids (Loligo gahi and Illex argentinus), common hake Merluccius hubbsi, and small octopuses (Schiavini et al. 1997). However, these diet studies were conducted with individuals from Tierra del Fuego (further south than our study area), so this information should be treated with caution until information on diet for the whole study area is available.

Brownell et al. (1998) indicated that despite the extensive overlap in their distribution, dusky and Peale's dolphins differ in their habitat use, and the dusky dolphin has a wider offshore distribution. However, recent data from a survey conducted in November 2009 shows that groups of Peale's dolphins were sighted near the continental slope between 41 and $43^{\circ} \mathrm{S}$ (authors' unpubl. data). On the other hand, the dusky dolphin is a mesopelagic feeder whose main prey is Argentine anchovy Engraulis anchoita (Koen 
Alonso et al. 1998). The highest ER of the dusky dolphin was predicted to occur in the central zone of our study area; this zone coincides with the location of the coastal fraction of the highest densities of Patagonian anchovy stock (Hansen et al. 2001, Buratti et al. 2006).

In the present study, Commerson's dolphin presented the most coastal distribution. The habitat preferences found for this species corresponded to the warm months. No sightings of Commerson's dolphin were made in the colder months (May, August, and October), suggesting maybe a different habitat preference in colder seasons. Pedraza (2008) found that depth does not seem to influence the distribution of this species, which is often found feeding at the mouths of the Patagonian rivers Chubut, Deseado, Coy Gallegos, and Bahía San Julián, all places with intense tide flows. In northern Patagonia, this dolphin shows pelagic and opportunistic feeding habits. But in areas with large tidal amplitudes (parts of the coast of the provinces of Santa Cruz and Tierra del Fuego), it uses benthic resources (Bastida et al. 1988). Therefore, there are differences in habitat use compared to the other species in the present study.

In the present study, the habitat models were not only explanatory (i.e. to understand what variables are important in habitat selection) but also predictive (i.e. to predict where dolphins are likely to occur given certain habitat types). From an ecological perspective, environmental variables are those of direct interest as they represent proxies for biological features that determine habitat quality (Heinrich 2006). The direct causal relationships underlying the observed distribution and habitat selection patterns are currently unknown. As is common in cetacean habitat studies, environmental features are considered proxies for the availability and distribution of critical resources, such as prey, mates, and shelter from predators, all of which are inherently difficult to determine or quantify reliably (Gowans \& Whitehead 1995, Fiedler et al. 1998, Reilly et al. 1998, Griffin \& Griffin 2003, Macleod et al. 2004, Croll et al. 2005).

Habitat modeling is a powerful analytical tool to investigate where animals are found, why they might occur there, and where they could be expected to occur (Boyce \& McDonald 1999, Rushton et al. 2004). However, the results from habitat models need to be evaluated carefully before conclusions are drawn or generalizations are made. It is important to consider that grid size affects the amount of effort and number of sightings within each cell. At larger grid sizes, the sighting rate is higher but the environmental conditions are averaged over a larger area (Hamazaki 2002, Redfern et al. 2006). An advantage of the use of habitat-selection models is that they can be refitted to incorporate both new sightings and expanded environmental data to clarify effects and to explore whether habitat use appears to be changing. It also provides a focus for more detailed studies to explore the mechanisms determining cetacean distribution and hence a better prediction of the effects of anthropogenic factors on conservation status (Cañadas et al. 2005).

The selected models could be improved by evaluating several spatial and temporal scales, because some predictor variables may have different significance at different scales. In addition, environmental predictor variables such as SST and Chl a vary between months. Therefore, including temporal variability may also improve descriptions of habitat use. Finally, knowledge of the distribution patterns and occurrence of small cetaceans in the Patagonian marine system provides a baseline understanding of how these species interact with each other and their environment. Such information should be considered when potential areas of conflict between coastal cetaceans and human activities are being planned. The main threats for small cetaceans in Patagonian waters are incidental mortality in fishing gear, indirect effects of fisheries, tourism interactions, and more recently, offshore oil exploration (Corcuera et al. 1994, Crespo et al. 1994, 1997b, 2000, Goodall et al. 1995, Dans et al. 1997, 2003, 2008, Coscarella et al. 2003). Habitat-preference modeling identified areas with higher rates of encounter for the species of small cetaceans studied, which therefore by implication are the areas more important for their conservation. These areas should be considered in future designs of marine protected areas.

Acknowledgements. This research received logistic and institutional support from Centro Nacional Patagónico (Consejo Nacional de Investigaciones Científicas y Técnicas of Argentina) and the University of Patagonia. Financial support was given by the Patagonian Coastal Zone Management Plan (GEF/PNUD/FPN), Agencia Nacional de Promoción Científica y Tecnológica (PICT 01-4030 A and PICT 11679), the Convention of Migratory Species (UNEP), Consejo Nacional de Investigaciones Científicas y Técnicas of Argentina (PID 320/99), Fundación BBVA (Biocon04), and Project PNUD ARG-02/018 (B-B27). We thank A. Chizzini, N. García, S. Acosta, J. C. Aguerrebere, M. Coscarella, M. Koen Alonso, and B. Berón Vera for their help during the flights as observers. We also thank the pilots and personnel of the airplane CASA C-212 of the Prefectura Naval Argentina (National Coast Guard of Argentina) for their help and understanding beyond all expectation. Thanks also are given to B. Rossiter, Cetacean Society International, for the grants to G.V.G., who attended the COLACMAR (Cuba). G.V.G. and M.D. were supported by a $\mathrm{PhD}$ fellowship from Consejo Nacional de Investigaciones Científicas y Técnicas of Argentina.

\section{LITERATURE CITED}

Acha EM, Mianzan H, Guerrero RA, Favero M, Bava J (2004) Marine fronts at the continental shelfs of austral South America: physical and ecological processes. J Mar Syst 44: 83-105 
Akaike H (1973) Information theory and an extension of maximum likelihood principle. In: Petran BN, Csàaki F (eds) Int Symp Inf Theory. Akadèemiai Kiadi, Budapest, p 267-281

Bailey H, Thompson PM (2009) Using marine mammal habitat modelling to identify priority conservation zones within a marine protected area. Mar Ecol Prog Ser 378:279-287

Bastida R, Lichtschein V, Goodall RNP (1988) Food habits of Cephalorhynchus commersonii off Tierra del Fuego. Rep Int Whal Comm Spec Issue 9:3-70

Baumgartner MF (1997) The distribution of Risso's dolphin (Grampus griseus) with respect to the physiography of the northern Gulf of Mexico. Mar Mamm Sci 13:614-638

Baumgartner MF, Mullin KD, May LN, Leming TD (2001) Cetacean habitats in the northern Gulf of Mexico. Fish Bull 99:219-239

Baumgartner MF, Cole TVN, Clapham PJ, Mate BR (2003) North Atlantic right whale habitat in the lower Bay of Fundy and on the SW Scotian Shelf during 1999-2001. Mar Ecol Prog Ser 264:137-154

Bearzi M (2005) Dolphin sympatric ecology. Mar Biol Res 1: $165-175$

Belkin IM (2009) Rapid warming of large marine ecosystems. Prog Oceanogr 81:207-213

Bjørge A (2001) How persistent are marine mammal habitats in an ocean of variability? In: Evans PGH, Raga JA (eds) Marine mammals: biology and conservation. Kluwer Academic/Plenum Publishers, New York, NY, p 63-91

Boyce MS, McDonald LL (1999) Relating populations to habitats using resource selection functions. Trends Ecol Evol 14:268-290

Brown CW, Winn HE (1989) Relationship between the distribution pattern of right whales, Eubalaena glacialis, and satellite-derived sea surface thermal structure in the Great South Channel. Cont Shelf Res 9:247-260

Brownell RL Jr (1974) Small odontocetes of the Antarctic. In: Bushnel VC (ed) Antarctic mammals. Antarctic Map Folio Series 18. American Geographic Society, New York, NY, p 15-19

Brownell RL Jr, Crespo EA, Donahue M (1998) Peale's dolphin, Lagenorhynchus australis. In: Ridgway S, Harrison $\mathrm{R}$ (eds) Handbook of marine mammals, Vol 6. The second book of dolphins and the porpoises. Academic Press, London, p 105-120

Buratti C, Cabreira A, Martos P (2006) Patrones de distribución del efectivo patagónico de anchoita Engraulis anchoita en primavera tardía durante los años 1998, 1999 y 2004. INIDEP. Informe Técnico (Technical report) Nro. 45

Burnham KP, Anderson DR (2002) Model selection and multimodel inference, 2nd edn. Springer-Verlag, New York, NY

Cabeza M, Araújo B, Wilson RJ, Thomas CD, Cowley MJR, Moilanen A (2004) Combining probabilities of occurrence with spatial reserve design. J Appl Ecol 41:252-262

Cañadas A, Sagarminaga R, García-Tiscar S (2002) Cetacean distribution related with depth and slope in the Mediterranean waters off southern Spain. Deep-Sea Res I 49: 2053-2073

Cañadas A, Sagarminaga R, De Stephanis R, Urquiola E, Hammond PS (2005) Habitat preference modelling as a conservation tool: proposals for marine protected areas for cetaceans in southern Spanish waters. Aquat Conserv 15:495-521

Carretta JV, Taylor BL, Chivers SJ (2001) Abundance and depth distribution of harbor porpoise (Phocoena phocoena) in northern California determined from a 1995 ship survey. Fish Bull (Wash DC) 99:29-39
Corcuera J, Monzón F, Crespo EA, Aguilar A, Raga JA (1994) Interactions between marine mammals and fisheries of Necochea and Claromecó (Buenos Aires, Province, Argentina). In: Perrin WF, Donovan GP, Barlow J (eds) Gillnets and cetaceans. Rep Int Whal Comm Spec Issue 15: 283-290

Coscarella MA, Dans SL, Crespo EA, Pedraza SN (2003) Potential impact of unregulated dolphin watching activities in Patagonia. J Cetacean Res Manag 5:77-84

Crespo EA, Corcuera J, Lopez Cazorla A (1994) Interactions between marine mammals and fisheries in some fishing areas of the coast of Argentina. Rep Int Whal Comm Spec Issue 15:269-281

Crespo EA, Pedraza SN, Coscarella M, García NA and others (1997a) Distribution and school size of dusky dolphins, Lagenorhynchus obscurus (Gray, 1928), in the Southwestern South Atlantic Ocean. Rep Int Whal Comm 47: 693-697

Crespo EA, Pedraza SN, Dans SL, Koen Alonso M and others (1997b) Direct and indirect effects of the highseas fisheries on the marine mammal populations in the northern and central Patagonian coast. J Northwest Atl Fish Sci 22: 189-207

Crespo EA, Koen Alonso M, Dans SL, García NA, Pedraza SN, Coscarella MA, González R (2000) Incidental catch of dolphins in mid-water trawls for southern anchovy off Patagonia. J Cetacean Res Manag 2:11-16

$>$ Croll DA, Marinovic B, Benson SR, Chavez FP, Black N, Ternullo R, Tershy BR (2005) From wind to whales: trophic links in a coastal upwelling system. Mar Ecol Prog Ser 289: $117-130$

Dans SL, Crespo EA, García NA, Reyes LM, Pedraza SN, Koen Alonso M (1997) Incidental mortality of Patagonian dusky dolphins in mid-water trawling: retrospective effects from the early 80's. Rep Int Whal Comm 47: 699-704

Dans SL, Koen Alonso M, Pedraza SN, Crespo EA (2003) Incidental catch of dolphins in trawling fisheries off Patagonia, Argentina: can populations persist? Ecol Appl 13: 754-762

Dans SL, Crespo EA, Pedraza SN, Degrati M, Garaffo GV (2008) Dusky dolphins and tourist interaction: effect on diurnal feeding behavior. Mar Ecol Prog Ser 369:273-285

de Haro JC, Iñiguez MA (1997) Ecology and behaviour of the Peale's dolphin, Lagenorhynchus australis (Peale, 1848) at Cabo Vírgenes (52 $\left.30^{\prime} \mathrm{S}, 68^{\circ} 28^{\prime} \mathrm{W}\right)$, Patagonia Argentina. Rep Int Whal Comm 47:723-727

Dobson AJ (2002) An introduction to generalized linear models. Chapman \& Hall/CRC, Boca Raton, FL

Embling CB, Gillibrand PA, Gordon J, Shrimpton J, Stevick PT, Hammond PH (2010) Using habitat models to identify suitable sites for marine protected areas for harbour porpoises (Phocoena phocoena). Biol Conserv 143:267-279

Evans PGH (2002) Habitat pressures. In: Perrin WF, Würsig B, Thewissen JGM (eds) Encyclopedia of marine mammals. Academic Press, San Diego, CA, p 545-548

Fiedler PC, Barlow J, Gerrodette G (1998) Dolphin prey abundance determined from acoustic backscatter data in eastern Pacific surveys. Fish Bull 96:237-247

Forcada J (2002) Distribution. In: Perrin WF, Würsig B, Thewissen JGM (eds) Encyclopedia of marine mammals. Academic Press, San Diego, CA, p 327-333

Forney KA (2000) Environmental models of cetacean abundance: reducing uncertainty in population trends. Conserv Biol 14:1271-1286

Garaffo GV, Dans SL, Pedraza SN, Crespo EA, Degrati M (2007) Habitat use by dusky dolphin in Patagonia: How predictable is their location? Mar Biol 152:165-177 
Garaffo GV, Dans SL, Crespo EA, Degrati M, Giudici P, Gagliardini DA (2010) Dusky dolphin: modeling habitat selection. J Mammal 91:54-65

Gibson LA, Wilson BA, Cahill DM, Hill J (2004) Spatial prediction of rufous bristlebird habitat in a coastal heathland: a GIS-based approach. J Appl Ecol 41:213-223

Goodall RNP, Schiavini ACM, Benegas LG, Galván P (1995) La captura incidental de delfines en Tierra del Fuego. Informe presentado a la Dirección General de Recursos Naturales y la Dirección General de Medio Ambiente de la Provincia de Tierra del Fuego, Antártida e Islas del Atlántico Sur

Goodall RNP, de Haro JC, Iñiguez MA, Norris KS (1997) Sightings and behavior of Peale's dolphins, Lagenorhynchus australis, with notes on dusky dolphins, Lagenorhynchus obscurus, off southernmost South America. Rep Int Whal Comm 47:757-775

Gowans S, Whitehead H (1995) Distribution and habitat partitioning by small odontocetes in the Gully, a submarine canyon on the Scotian Shelf. Can J Zool 73:1599-1608

Griffin RB, Griffin NJ (2003) Distribution, habitat partitioning and abundance of Atlantic spotted dolphins, bottlenose dolphins, and loggerhead sea turtles on the eastern Gulf of Mexico continental shelf. Gulf Mex Sci 21:23-34

Hamazaki T (2002) Spatiotemporal prediction models of cetacean habitats in the mid-western North Atlantic Ocean (from Cape Hatteras, North Carolina, USA to Nova Scotia, Canada). Mar Mamm Sci 18:920-939

Hansen JE, Martos P, Madirolas A (2001) Relationship between spatial distribution of the Patagonian stock of Argentine anchovy, Engraulis anchoita, and sea temperatures during late spring to early summer. Fish Oceanogr 10:193-206

Heinrich S (2006) Ecology of Chilean dolphins and Peale's dolphins at Isla Chiloé, southern Chile. PhD thesis, University of St. Andrews

Hill JK (1999) Butterfly spatial distribution and habitat requirements in a tropical forest: impacts of selective logging. J Appl Ecol 36:564-572

Hooker SK, Gerber LR (2004) Marine reserves as a tool for ecosystem-based management: the potential importance of megafauna. Bioscience 54:27-39

Hooker SK, Whitehead H, Gowans S (1999) Marine protected area design and the spatial and temporal distribution of cetaceans in a submarine canyon. Conserv Biol 13: 592-602

Ingram SN, Walshe L, Johnston D, Rogan E (2007) Habitat partitioning and the influence of benthic topography and oceanography on the distribution of fin and minke whales in the Bay of Fundy, Canada. J Mar Biol Assoc UK 87: 149-156

Jaquet N, Gendron D (2002) Distribution and relative abundance of sperm whales in relation to key environmental features, squid landings and the distribution of other cetacean species in the Gulf of California, Mexico. Mar Biol 141:591-601

Jeganathan P, Green RE, Norris K, Vogiatzakis JN and others (2004) Modelling habitat selection and distribution of the critically endangered Jerdon's courser Rhiptilus bitorquatus in scrub jungle: an application of a new tracking method. J Appl Ecol 41:224-237

Johnston DW, Thorne LH, Read AJ (2005a) Fin whales Balaenoptera physalus and minke whales Balaenoptera acutorostrata exploit a tidally driven island wake ecosystem in the Bay of Fundy. Mar Ecol Prog Ser 305:287-295

> Johnston DW, Westgate AJ, Read AJ (2005b) Effects of fine scale oceanographic features on the distribution and movements of harbour porpoises Phocoena phocoena in the Bay of Fundy. Mar Ecol Prog Ser 295:279-293
Kaschner K (2004) Modelling and mapping of resource overlap between marine mammals and fisheries on a global scale. PhD dissertation, University of British Columbia, Vancouver

Koen Alonso M, Crespo EA, García NA, Pedraza SN, Coscarella M (1998) Diet of dusky dolphins, Lagenorhynchus obscurus, in waters off Patagonia, Argentina. Fish Bull 96:366-374

Lescrauwaet AK (1997) Notes on the behaviour and ecology of the Peale's dolphin, Lagenorhynchus australis, in the Strait of Magellan, Chile. Rep Int Whal Comm 47:747-755

Littaye A, Gannier A, Laran S, Wilson JPF (2004) The relationship between summer aggregation of fin whales and satellite-derived environmental conditions in the northwestern Mediterranean Sea. Remote Sens Environ 90:44-52

> Macleod K, Fairbairns R, Gill A, Fairbairns B, Gordon J, BlairMyers C, Parsons ECM (2004) Seasonal distribution of minke whales Balaenoptera acutorostrata in relation to physiography and prey off the Isle of Mull, Scotland. Mar Ecol Prog Ser 277:263-274

MacNally R (2000) Regression and model-building in conservation biology, biogeography and ecology: The distinction between - and reconciliation of - 'predictive' and 'explanatory' models. Biodivers Conserv 9:655-671

McCullagh P, Nelder JA (1989) Generalized linear models, 2nd edn. Chapman \& Hall/CRC, Boca Raton, FL

> Mendes S, Turrell W, Lutkebohle T, Thompson P (2002) Influence of the tidal cycle and a tidal intrusion front on the spatio-temporal distribution of coastal bottlenose dolphins. Mar Ecol Prog Ser 239:221-229

Mitchell ED (1975) Report of the Meeting on Smaller Cetaceans, Montreal, April 1-11, 1974, Subcomm Small Cetaceans, Sci Comm, IWC. J Fish Res Board Can (Spec Issue) 32(7):875-1242

Panigada S, Notarbartolo di Sciara G, Zanardelli M, Airoldi S, Borsani JF, Jahoda M (2005) Fin whales (Balaenoptera physalus) summering in the Ligurian Sea: distribution, encounter rate, mean group size and relation to physiographic variables. J Cetacean Res Manag 7:137-145

Panigada S, Zanardelli M, MacKenzie M, Donovan C, Mélin M, Hammond PS (2008) Modelling habitat preferences for fin whales and striped dolphins in the Pelagos Sanctuary (Western Mediterranean Sea) with physiographic and remote sensing variables. Remote Sens Environ 112: $3400-3412$

Pedraza SN (2008) Ecología poblacional de la tonina overa, Cephalorhynchus commersonii, (Lacépède, 1804) en el litoral patagónico. $\mathrm{PhD}$ thesis, Universidad de Buenos Aires

Piola A (2008a) Temperatura superficial del mar. In: Boltovskoy D (ed) Atlas de sensibilidad ambiental de la costa y el mar Argentino. Secretaría de Ambiente y Desarrollo Sustentable, Buenos Aires. http://atlas.ambiente.gov.ar

Piola A (2008b) Clorofila. In: Boltovskoy D (ed) Atlas de sensibilidad ambiental de la costa y el mar Argentino. Secretaría de Ambiente y Desarrollo Sustentable, Buenos Aires. http://atlas.ambiente.gov.ar

Piola A (2008c) Oceanografía física. In: Estado de conservación del mar Patagónico. Foro para la Conservación del Mar Patagónico y Áreas de Influencia, Puerto Madryn, p 8-12

Redfern JV, Ferguson MC, Becker EA, Hyrenbach KD and others (2006) Techniques for cetacean-habitat modeling. Mar Ecol Prog Ser 310:271-295

Reilly SB (1990) Seasonal changes in distribution and habitat differences among dolphins in the eastern tropical Pacific. Mar Ecol Prog Ser 66:1-11

Reilly SB, Fiedler PC (1994) Interannual variability of dolphin 
habitats in the eastern tropical Pacific. I. Research vessel surveys 1986-1990. Fish Bull (Wash DC) 92:434-450

Reilly SB, Fiedler PC, Forney KA, Barlow J (1998) Partitioning geo-spatial and oceanographic patterns in cetacean habitat analyses. In: World Mar Mamm Sci Conf, 20-25 January, Monte Carlo, Monaco, p 112

Rivas AL (2010) Spatial and temporal variability of satellitederived sea surface temperature in the Southwestern Atlantic Ocean. Cont Shelf Res 30:752-760

Roughgarden J (1976) Resource partitioning among competing species: a coevolutionary approach. Theor Popul Biol 9:388-424

Rushton SP, Ormerod SJ, Kerby G (2004) New paradigms for modeling species distribution? J Appl Ecol 41:193-200

Schiavini ACM, Goodall RNP, Lescrauwaet AK, Koen Alonso M (1997) Food habits of Peale's dolphin, Lagenorhynchus australis, review and new information. Rep Int Whal Comm 47:827-834

Siegel S, Castellan NJ (1995) Estadística no paramétrica aplicada a la ciencia de la conducta, 4th edn. Editorial Trillas, México D.F.

Editorial responsibility: Michael Castellini,

Fairbanks, Alaska, USA
Torres LG, Rosel PE, D'Agrosa C, Read AJ (2003) Improving management of overlapping bottlenose dolphin ecotypes through spatial analysis and genetics. Mar Mamm Sci 19: 502-514

Tynan CT (1998) Ecological importance of the southern boundary of the Antarctic Circumpolar Current. Nature 392:708-710

Van Waerebeek K (1992) Population identity and general biology of the dusky dolphin Lagenorhynchus obscurus (Gray, 1828) in the Southeast Pacific. PhD thesis, Institute for Taxonomic Zoology, University of Amsterdam

Waring GT, Hamazaki T, Sheehan D, Wood G, Baker S (2001) Characterization of beaked whale (Ziphiidae) and sperm whale (Physeter macrocephalus) summer habitat in shelfedge and deeper waters off the northeast US. Mar Mamm Sci 17:703-717

Whitehead H, Reeves RR, Tyack PL (2000) Science and the conservation, protection, and management of wild cetaceans. In: Mann J, Connor RC, Tyack PJ, Whitehead H (eds) Cetacean societies: field studies of dolphins and whales. University of Chicago Press, Chicago, IL, p 308-322

Submitted: July 2, 2010; Accepted: October 30, 2010

Proofs received from author(s): January 7, 2011 